\title{
A STUDY ON THE IMPACT OF GLOBALIZATION ON INDIAN RURAL MARKETS
}

\begin{tabular}{|l|l}
\hline A Rajendraprasad, & V Sandhyarani, \\
Assistant Professor, & Assistant Professor \\
Department of Business Management, & Department of Business Management, \\
Sree Chaitanya Institute of Technological Sciences, & Sree Chaitanya P.G. College, \\
LMD Colony, Karimnagar & LMD Colony, Karimnagar \\
rajendraprasadalla123@gmail.com & sandhyarani.vade@gmail.com \\
\hline
\end{tabular}

\section{ABSTRACT}

Globalization is not at all a new term for us as we are experiencing the tremendous change in our environment which is purely a result of it. The change is clear and shown a considerable effect on rural markets. Through this article, an attempt is made to put on paper the important changes brought by globalization in rural markets.

Keywords: Globalization, Urbanization, Census, Rural Area, Market.

\section{INTRODUCTION:}

Whenever we speak of globalization in Indian context, we generally think of rural markets and the change that they have seen. We many times recollect glory of our childhood days before last decade which makes us little bit upset as we don't find them today. It is this concept which motivated Goreti Venkanna a famous writer and singer of Telangana state to write a song called 'palle kanneru pedutundo' which won him the kalarathna award moreover he won the hearts of millions with his literature on present rural situation in India. we cannot completely blame globalization for worsened rural conditions but it has a considerable role in it.

What is a rural area? According to Population Census of India 'all areas which are not categorized as urban area are considered as rural area'. What is an urban area? According to Population Census of India the following are considered as urban areas

a) All places with a municipality, corporation, cantonment board or any other notified town area committees is known as statutory town.

b) All other places which satisfy following criteria are called as census town

- A minimum population of 5000 .

- At least $75 \%$ of male workers engaged in non agricultural persuits

- A density of population of at least 400 per sq. $\mathrm{km}$.

What are rural markets? In traditional sense market represent a place 
ELK

Asia Pacific Journals

where buyers and sellers meet together but according to demand concept of market means potential buyers. So, rural market means potential buyers in rural markets. The marketers try to identify consumer needs and satisfy them.

1. Objective : To study the impact of globalization in rural customers

2. Scope of Study: The study primarily focuses on Indian rural markets and also sheds light on marketing practices from traditional to modern times. It takes in to account the issues and challenges of Indian rural as a consequence of globalization.

\section{The Effect of Globalization on Indian}

Rural Markets: The present day businesses are mainly concentrating on globalization as it makes the market open for entire world. Speaking in Indian context globalization has effected Indian markets in many ways especially the rural markets. It is globalization which has resulted in the emergence of rural markets and there is a great swift in urbanization after MNC's and other global corporations hit Indian rural markets. Foreign corporations are using strategic tools like alliances, mergers and acquisitions or starting subsidiaries in
ELK Asia Pacific Journals - Special Issue

ISBN: 978-81-930411-9-2

India to capture Indian markets especially in rural areas. Globalization has not only changed rural markets but also the marketing practices in rural areas. The impact of globalization on Indian rural markets were discussed in the following points

> Indian rural markets have become the best market places for world corporations as they have seen a rapid development in in terms of education, purchasing power, information seeking etc... globalization is one of the major reasons for this changing rural markets and it is global corporations who have optimized this change.

The culture and lifestyles of rural markets have changed to a great extent as the foreign cultures have exposed to Indian rural markets. It is a notable point that westernization is not only seen in metropolitan cities but also in urban and rural areas.

Most of the marketing practices in rural areas were turned from unorganized to organized form. It has created greater convenience for marketing activities. 
Majority of Indian population belong to rural areas and it is globalization which turned on the rural markets and the consequence is increased urbanization. The following table shows the rural and urban population in India. In Indian history of census 2011 is the year where increased urbanization is seen.

INDIAN POPULATION (in crores)

\begin{tabular}{|l|c|c|c|}
\hline \multicolumn{1}{|c|}{ YEAR } & 2001 & 2011 & Difference \\
\hline RURAL & 74.3 & 83.3 & 18.1 \\
\hline URBAN & 28.6 & 37.7 & 9.0 \\
\hline TOTAL POPULATION & 102.9 & 121.0 & 9.1 \\
\hline
\end{tabular}

(Source Indian population census, 2011)

Globalization created more competition in the Indian markets. It resulted in more product choice, increased product awareness with plenty of competing brands in rural markets.

$>$ Indians .i.e. practices which took birth in India in marketing practices at rural areas were almost dried out. Today with the effect of globalization the traditional marketing practices like Mandy's; periodic fairs etc... were struggling for their existence.

In India rural markets stood as an icon for green consciousness but anyway it was past .globalization resulted in excess pollution in rural areas as MNC's and other foreign corporations are not following eco friendly marketing practices. Globalization was also one of the reasons for deforestation in rural areas.

Many domestic products especially hand made products are unable to compete with foreign machine made products and lost demand in rural areas.

Globalization has created many new opportunities in Indian markets. Use of internet in marketing has shown a drastic effect on rural markets like creating convenience in place, 
ELK

Asia Pacific Journals

procession and awareness of customers.

The export opportunities for Indian rural markets were widened. Agricultural outputs and other hand made products have enough demand in in international markets.

$>$ Globalization has effected the psychologies of rural consumers to a very great extent. Today a rural customer needs instant products instead of working hard. This is one of the reason why they blindly started believing brands and ignoring the contribution of great Indian research outputs. For instance Subash Phalekar has contributed a lot for agricultural sector with his research but astonishingly many Indians doesn't know his name.

With the emergence of globalization ethical values especially in rural marketing were reduced to a great extent.

Agriculture is treated to be the backbone of India but the interest of Indian rural youth was turned on towards corporate jobs which reduced productivity and proportion
ELK Asia Pacific Journals - Special Issue ISBN: 978-81-930411-9-2

of participation of Indian youth in agriculture was reduced.

Globalization resulted in unemployment of many rural professionals like goldsmith, pot makers, workers of handicrafts, handlooms etc...

Conclusion: With the above discussion it is clearly found that globalization has shown many consequences on Indian rural markets. Now we need to know whether these consequences are good or bad. The effect of globalization on rural markets is good or bad? Is always an hypothetical question. But we can definitely say that the negative consequences seems to be dominating over positive consequences. Despite of good that is globalization has done to the Indian rural markets, it has brought enormous changes to the culture, lifestyle, hardworking nature and attitudes of rural customers. As rural areas are treated to be the dominating markets in India, globalization by effecting rural markets has shown considerable effect 
on Indian economy. At the same time we cannot ignore the positive consequences of globalization to rural markets as they educated rural markets in many ways.

\section{References:}

[1] C.S.G. Krishnamacharyulu \& Lalitha Ramakrishnan,'Rural Marketing”, $2^{\text {nd }}$ edition, 2003, Pearson education.

[2] Manab Adhikary, "Global Business Management", First edition, 2001, Macmillan Business Books. 